\title{
Mild encephalopathy in a rotavirus infected patient with hyperamylasaemia
}

\author{
Koji Yokoyama, Akira Yoshida
}

Japanese Red Cross Wakayama Medical Center, Wakayama, Japan

\section{Correspondence to Dr Koji Yokoyama, kojiy@kuhp.kyoto-u.ac.jp}

Accepted 18 August 2016
CrossMark

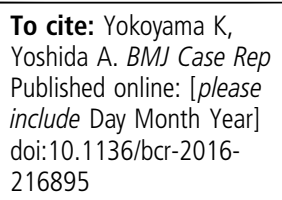

\section{DESCRIPTION}

A previously healthy 8 -year-old Japanese girl was admitted to hospital with a 2-day history of repeated vomiting, watery diarrhoea and abdominal pain, and a day's history of fever, complicated by sudden disturbance of consciousness on the day of admission. She was fully vaccinated (excluding a rotavirus vaccine) and had no recent history of foreign travel or contact with animals. However, her younger sister (aged 3 years), who did receive a rotavirus vaccine, suffered from diarrhoea 1 week earlier. The patient appeared mildly dehydrated and drowsy, with transient periods of agitation and a Glasgow Coma Scale score of 9 (eyes 2, verbal 2, motor 5). She blinked often and mumbled during periods of unconsciousness. The abdomen was mildly distended, with slightly hyperactive bowel sounds. Laboratory tests revealed the following: serum sodium $129 \mathrm{mmol} / \mathrm{L}$ and potassium $2.0 \mathrm{mmol} / \mathrm{L}$, along with increased levels of amylase (636 U/L; normal value $40-120)$, lipase $(255 \mathrm{U} / \mathrm{L}$; normal value 13-60) and pancreatic amylase (121 U/L; normal value 18-53). Serum calcium, phosphorus, and blood glucose levels and renal and liver function tests were normal. Cerebrospinal fluid (CSF) analysis and whole body enhanced CT scan revealed no abnormalities. T2-weighted and diffusion-restricted MRI of the brain (bMRI) revealed marked hyperintensity in the splenium of

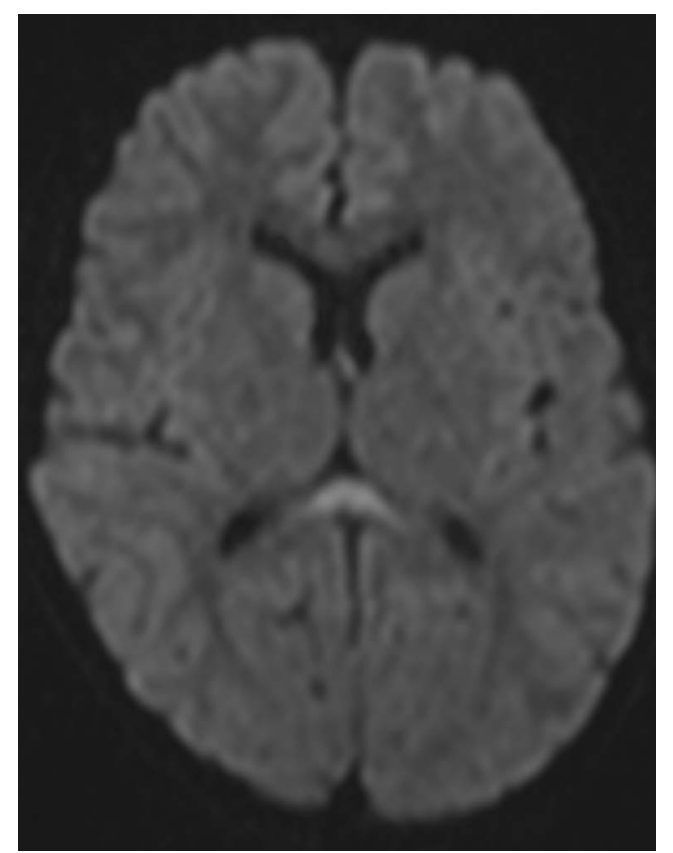

Figure 1 Diffusion-weighted MRI of the brain performed on day 3 after the onset of illness showing an intensified signal in the splenium of the corpus callosum. the corpus callosum (figure 1). Rotavirus antigen was detected in a stool specimen (ELISA) and genome in CSF (RT-PCR). The genotype was G3P8. No other pathogen was detected in the CSF. She was treated with intravenous crystalloids, and her clinical condition improved over the subsequent 2 days, with gradual resolution of symptoms. Fatty and proteinaceous foods were gradually integrated and well tolerated. A follow-up bMRI and abdominal ultrasound scan 7 days after admission revealed no abnormalities, with complete disappearance of the original lesion. This course was compatible with mild encephalitis/encephalopathy with a reversible splenial lesion (MERS). ${ }^{1}$ Laboratory data showed normalisation of pancreatic amylase $(47 \mathrm{U} / \mathrm{L})$, lipase $(45 \mathrm{U} / \mathrm{L})$ and electrolyte levels. The patient recovered completely without any neurological complications and was discharged after 1 week.

The course of this patient presents two important clinical findings. First, patients can suffer from rotavirus infection associated with MERS. Second, hyperamylasaemia is complicated by rotavirus enterocolitis. It is possible that MERS and hyperamylasaemia might happen at the same time as complications of rotavirus infection. MERS is a type of acute encephalopathy characterised by transient splenic lesions with high-signal intensity on diffusion-weighted bMRI. Rotavirus is a causative agent of MERS. ${ }^{1}$ Hyperamylasaemia which is accompanied by rotavirus-associated enterocolitis seemed to be a mild disease. ${ }^{2}$ Pancreatic hyperamylasaemia and hyperlipidaemia were found in patients with acute pancreatitis (AP). On the other hand, nearly a quarter of children with AP develop severe complications, and the mortality rate is $\sim 4 \% .^{3}$ There was a difference between rotavirus -associated AP and others in terms of severity and prognosis. The pathogenesis of hyperamylasaemia with rotavirus infection is not well understood and further studies are needed to better understand how rotavirus could cause encephalopathy and hyperamylasaemia, if predisposing factors exist, and real incidence of this condition.

\section{Learning points}

- This case illustrates the protean manifestations of rotavirus infection including MERS and hyperamylasaemia.

- In a clinical setting the physician should pay attention to these complications. 
Contributors $\mathrm{KY}$ and $\mathrm{AY}$ designed the study and collected and analysed data. $\mathrm{KY}$ wrote the manuscript. AY gave technical support and conceptual advice. All authors read and approved the final manuscript.

Competing interests None declared.

Patient consent Obtained.

Provenance and peer review Not commissioned; externally peer reviewed.

\section{REFERENCES}

1 Tada H, Takanashi J, Barkovich AJ, et al. Clinically mild encephalitis/encephalopathy with a reversible splenial lesion. Neurology 2004;63:1854-8.

2 Parri N, Innocenti L, Collini S, et al. Acute pancreatitis due to rotavirus gastroenteritis in a child. Pediatr Emerg Care 2010;26:592-3.

3 Lautz TB, Chin AC, Radhakrishnan J. Acute pancreatitis in children: spectrum of disease and predictors of severity. J Pediatr Surg 2011;46:1144-9.

Copyright 2016 BMJ Publishing Group. All rights reserved. For permission to reuse any of this content visit http://group.bmj.com/group/rights-licensing/permissions.

BMJ Case Report Fellows may re-use this article for personal use and teaching without any further permission.

Become a Fellow of BMJ Case Reports today and you can:

- Submit as many cases as you like

- Enjoy fast sympathetic peer review and rapid publication of accepted articles

- Access all the published articles

- Re-use any of the published material for personal use and teaching without further permission

For information on Institutional Fellowships contact consortiasales@bmjgroup.com

Visit casereports.bmj.com for more articles like this and to become a Fellow 